荤炎患者にみられた脾動脈瘤の一治験例

\author{
橋本市民病院外科 前 田 和 良 戸田 慶五郎 \\ 半羽健二山本誠己 \\ 和歌山医科大学第一病理 田 中 智之
}

\title{
SPLENIC ARTERY ANEURYSM WITH PANCREATITIS, REPORT OF A CASE
}

Kazuyoshi MAEDA, Keigoro TODA, Kenji HANBA and Seiki YAMAMOTO

Department of Surgery, Hashimoto Gity Hospital

Tomoyuki TANAKA

Department of The First Pathology, Wakayama Medical College

数年にわたり上腹部の激痛発作を繰り返してきた36歳，男子の勝炎患者に，左上腹部の 小児手拳大有痛性腫溜を触知したため，腹腔動脈撮影を施行した。これにより，脾動脈主 枝起始部に径約 $2 \mathrm{~cm}$ の球状の動脈瘤が描出され，触診での腫瘤の位置と一致した。開腹 すると，膵体部に径約 $8 \mathrm{~cm}$ 大の球状の仮性变胞があり，さらにこれを切開すると内膫に 径約 $3 \mathrm{~cm}$ 大の球状の動脈瘤が認められた。脺尾部は法とんど壊死自謴していた。脾と共

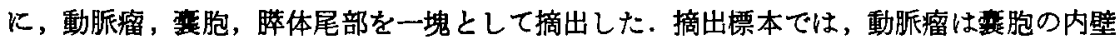
後面と連らなり，また動脈㿔壁は約 $1.5 \mathrm{~cm}$ の厚さをなし後壁にて脾動脈側壁と径約 $7 \mathrm{~mm}$ 大の円孔をるつて通していた，病理組織学的には，動脈㾗は，非特異的な慢性動脈炎を示 す脾動脈之の移行部より次第に内膜が線維性に肥厚し，弾性板も消失していた，膵は慢性 睡炎像を呈し，動脈瘤はこの资症の波及によるものと思われた，術後経過は良好で勝桨発 作は消矣した。

著者の集計し得た本邦での脾動脈瘤の症例は自験例を含めて63例で，この5ち術前訅断 されたものは39例であつた，発生原因別にみると，門脈圧六進症30例，動脈硬化症13例， 血管壁の先天性異常 7 例，動脈の限局性炎症 4 例，他仕不詳であつた. 動脈の限局性炎 症の原疾患は，梅毒，Behçet 症候群が各 1 例，扰上び自験例を含めた勝炎の 2 例であつ た. な打欧米に打いても膵炎に合併して脾動脈瘤がみられた報告は，4例にすぎなかつ た.

今後，腹胫動脈影影で膵炎症例にも脾動脈瘤が多数発見されるるのと思われる。

\section{緒 言}

腹部主幹動脈の動脈瘤は, 最近の選択的血管撮影の普 及により術前に多数診断されるようになった。なかで も, 脾動脈瘤は最も多く発生し"，本邦では1911年吉 田 ${ }^{22}$ 以来自験例を入れて63例の報告がある。しかし，膵 资の加療中腹控動脈撮影により脾動脈瘤が確諗された症 例は，自験例のみである。なお，本症例では大量の右胸 水貯留後の高度な葉間胁膜肥厚と, 脾動脈瘤を包む仮性
搭毫胞がみられている。

脾動脈瘤の発生原因特に膵炎との関連について若干の 文献的考察を行ならと共に，著者の集計し得た脾動脈瘤 症例を検討し，合せて報告する。

应列

36葴，男子, 会社員.

主訴 : 上腹部激痛

家族歴：特記事項なし。 
既往歴：気管支喘息あり，飲酒癖なし。

現病歴：昭和45年頃より左上腹部痛が時なあり，某医 にて膵炎の診断を受けていた。昭和49年 3 月より約半年 間, 右胸水を伴ら膆炎にて某病院内科で入院加療を受け たが，その後も上腹部の激痛発作を反復して当院内科に 3 度入退䟚をくり返した. 昭和52年 5 月 12 日同様の発作 にて救急来院し，当科に入院した。

入院時現症：体格中等度，栄養中中不良，皮店軽度乾 嬠. 顔貌苦悶状，荅白，血圧 $120 / 80 \mathrm{mmHg}$. 脈拍78/分 整, 体温 $37^{\circ} \mathrm{C}$. 結膜は軽度省血状であるが黄㡺なし. 舌 苔軽度, 預部異常なし、胸部，右全肺野濁音を呈し，肺 旰境界不明, 呼吸音も右肺で非常に弱く, しか子漧性ラ 音を聴取する，心音清純. 腹部，平坦，上腹部は硬く， 胳上部やや左側奇りに小児手拳大の王痛を伴う非可動 性，弾性硬の腫瘤を触知する．肝，脾，腎共に触れず。 足背浮尰なし.

\section{入院時検查成䊗：}

- 血液, 尿検查 (表 1 ).

血清および尿中フミラーゼ值の軽度上昇, OGTTで の境界型血糖曲線を示す以外異常なし.

・胸部レ線像

高度な右葉間助膜肥厚を諗める。
・腹部レ線像

石灰化像等の異常陰影はない。

- DIC

胆道系に異常所見はない。

- 胃部レ線透視

脊柱と胃壁との間隙の拡大をみるが，胃壁の拍動性陰 影欠損は認めない。

・缕シンチグラム

${ }^{75} \mathrm{Se}-$ Methionine $300 \mu \mathrm{Ci}$ の投与で, 接の出は全く みられない.

・腹腔動脈撮影 (写事 1 ).

脾動脈主枝起始部近くに球状の動脈瘤を認め，触診で の尰瘤の位㯰とほぼ一致する。

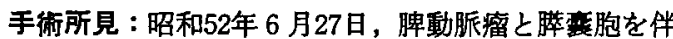
ら壊死性脺炎の診断のもとに，上腹部正中切開にて開腹 する，腹水はなく，大絧が腹膜に痣着する．肝は腫大せ ず，表面平滑，弾性軟で，色調も正常であり，また脾の 腫大る認めない.大絧を開くに，粹体部頭側奇りに径 $8 \mathrm{~cm}$ 大の球状の要胞あり脺実質内に埋没していて，明 瞭な被膜はなく，周囲脺実質よりの虽離は困難で，易出 血性である.このため，栾胞を切開し暗灰緑色の液状内 容物約 $100 \mathrm{ml}$ を吸引除去するに，内腔に径約 $3 \mathrm{~cm}$ 大の

表 1 血液・尿検枯成楼

\begin{tabular}{|c|c|c|c|c|c|c|}
\hline \multirow[t]{6}{*}{ 血 } & \multirow{2}{*}{ 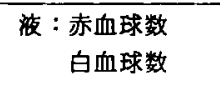 } & \multirow{2}{*}{$\begin{array}{l}395 \text { 万 } \\
6000\end{array}$} & \multicolumn{2}{|c|}{ 尿アミラーゼ } & \multicolumn{2}{|l|}{1720 Somogyi u. } \\
\hline & & & PSP & 15 分值 & $40 \%$ & \\
\hline & $\mathrm{Hb}$ & $13.1 \mathrm{~g} / \mathrm{dl}$ & & 120 分値 & $87 \mathscr{6}$ & \\
\hline & $\mathrm{Ht}$ 値 & $38 \%$ & 梅毒反応 & & 陰性 & \\
\hline & 出血時間 & 2 分 30 秒 & CRP & & $(+)$ & \\
\hline & 凝固時間 & 12分 & RA & & $(-)$ & \\
\hline \multirow[t]{8}{*}{ 血 } & 清 : 総蛋白 & $6.5 \mathrm{~g} / \mathrm{dl}$ & ASLO & & 160 & \\
\hline & $A / G$ 比 & 1.25 & 赤沈 & 1 時間値 & $22 \mathrm{~cm}$ & \\
\hline & $\mathrm{Na}$ & $144 \mathrm{mEq} /$ & OGTT & & & \\
\hline & $\mathrm{K}$ & $4.3 "$ & & 血糖値 & インスリン值 & 沓糖 \\
\hline & $\mathrm{Cl}$ & 104 & 0 分 & $120 \mathrm{mg} / \mathrm{dl}$ & $17.6 \mu \mathrm{u} / \mathrm{ml}$ & $(-)$ \\
\hline & $\mathrm{Ca}$ & $9.2 "$ & 30 & 260 & 94.9 & $(-)$ \\
\hline & $\mathrm{Mg}$ & $2.7 "$ & 60 & 170 & 27.0 & $(-)$ \\
\hline & アミラーゼ & 236 Somogyi u. & 90 & 200 & 11.9 & $(-)$ \\
\hline \multicolumn{2}{|c|}{ 肝機能：総ビリルビン } & $0.4 \mathrm{mg} / \mathrm{dl}$ & 120 & 130 & 19.5 & $(-)$ \\
\hline & ZTT & $6.4 \mathrm{u}$. & 180 & 130 & 7.2 & $(-)$ \\
\hline & TTT & $2.1 \mathrm{u}$ & & & & \\
\hline & GOT & $17 \mathrm{Ka} . \mathrm{u}$. & & & & \\
\hline & GPT & $13 \mathrm{Ka} . \mathrm{u}$. & & & & \\
\hline & $\mathrm{LDH}$ & 217 Wrob. u. & & & & \\
\hline & $\mathrm{Al}-\mathrm{P}$ & $8.7 \mathrm{~K} . \mathrm{Au}$. & & & & \\
\hline & 総コレステロ & $182 \mathrm{mg} / \mathrm{dl}$ & & & & \\
\hline
\end{tabular}


写克 1 腹腔功脈撮影

脾動脈主枝に，その起始部より約 $4 \mathrm{~cm}$ の部に径約 $2 \mathrm{~cm}$ の球状の動脈瘤をみる。

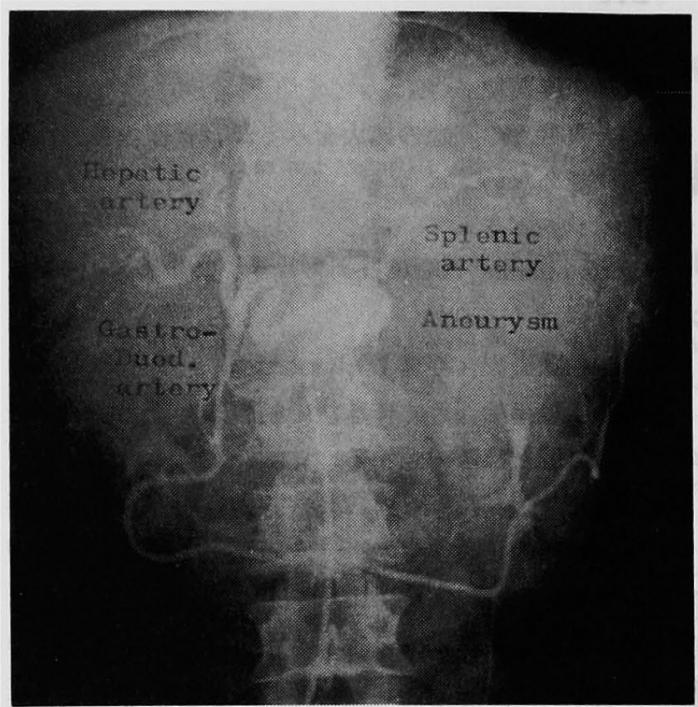

球状の動脈瘤を認める．中枢側脾動脈を宾胞近くの膵実 質内にて結禁切離し，この部で膵を横離断して膵体屁部 を黄胞・動脈瘤と共に後腹膜腔より遊離する．脺尾部は ほとんど壊死自潰している．次いで左横皮切を加え術野 を広げると，左横隔膜下，胃および脾周囲に以前からの 膵炎の遣残物と思われる死赤色のゼリ一状あるいは壊死 状物質が多量付着する.膵体尾部を脾と共に摘出する。

摘出標本 の肉眼的所見：睟垩胞の壁は, 境界不明瞭 で，䏽実質に移行し，堆胞内には， $4 \times 3 \times 3 \mathrm{~cm}$ 大，球 形で表面平滑，弾性硬の動脈瘤をみる。動脈瘤は，膆玨 胞の後壁と連なり剥離できない，動脈瘤を切開する に，壁は約 $1.5 \mathrm{~cm}$ の厚さで，血栓をいれ，後壁に写卉 2 ， 3 のごとく脾動脈側壁と径約 $7 \mathrm{~mm}$ 大の円孔をるっ て通じている。

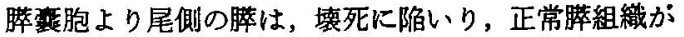
みられない，脾は横隔膜面に灰褐色の厚い苔を付すが腯 大せず，弾性軟である。

病理組鐡学的所見：膆変胞壁は線維珄結合織よりな り, 出血巣, 単核性の細胞浸潤および一部には肉牙組織 の形成がみられる。蘘胞の後壁では，線維性結合織中に 膵組織の残存がみられる、勝は小葉あるいは島に著変は ないが，小葉間の結合織は高度に増生し，写或 4 のよう に一部では著明に增生した結合織中に小葉が認められ， acinal atrophy の所見を呈する.しかし, それらの線維
写卉 2 摘出標本

脾動脈瘤は，後壁にて径約 $7 \mathrm{~mm}$ 大の開口をむつて 脾動脈と通じる。（脾動眽へソンデを插入している.）

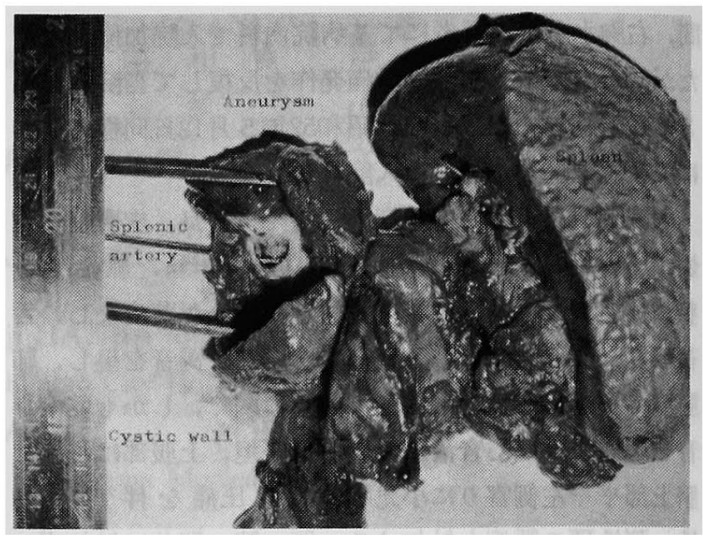

写乐 3 摘出標本割面

膵较胞の壁の境界は不明膫で，周辺の傽は壊死状を 呈し，後壁において動脈瘤とつらなる、動脈瘤内壁 は，層状の血栓を付着し $1 \sim 1.5 \mathrm{~cm}$ の厚さを示す。

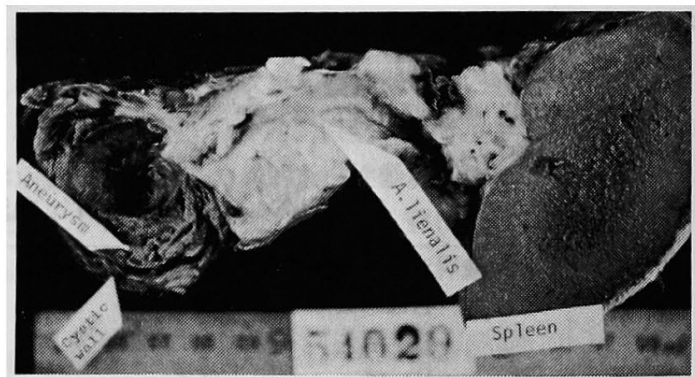

性結合織中におけるリンパ球などの炎症性細胞の浸潤は 比較的軽度である，導管は所々で著明に拡張，迁曲を示 している. 明瞭な pancreatic necrosis や fat necrosis は みられないが，これらの所見はいつれも慢性脺炎の所見 を示するのである．脾動脈は動脈瘤との移行部で硬化性 の病変が軽度にみられる程度であり, 写真 5 にみられる よ5に, 動脈瘤は次第にその内膜が線維性に肥厚し出血 および層状の血栓形成がみられる．血栓は部分的にその 器質化がみられ，時間的には古いものである，これらを PTAH 染色でみると正常の弾性板は移行部より離れる につれ浮腫状を呈し，断裂したりして，動脈瘤の部では 完全に消失している. fibrous に肥厚している動脈壁の 一部扣よびその外膜にはりンパ球の軽度の浸潤がみら れ，非特異的な僈性の動脈炎の存在がみられた．多分こ れは慢性膆炎の波及によるものと思われた。抙の被膜は 
写点 4 膵組唡像 (H.E.)

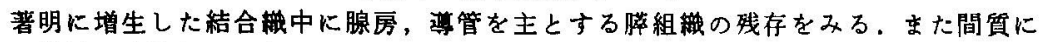
は慢性炎症性細胞の蛏度の浸潤がみられる。

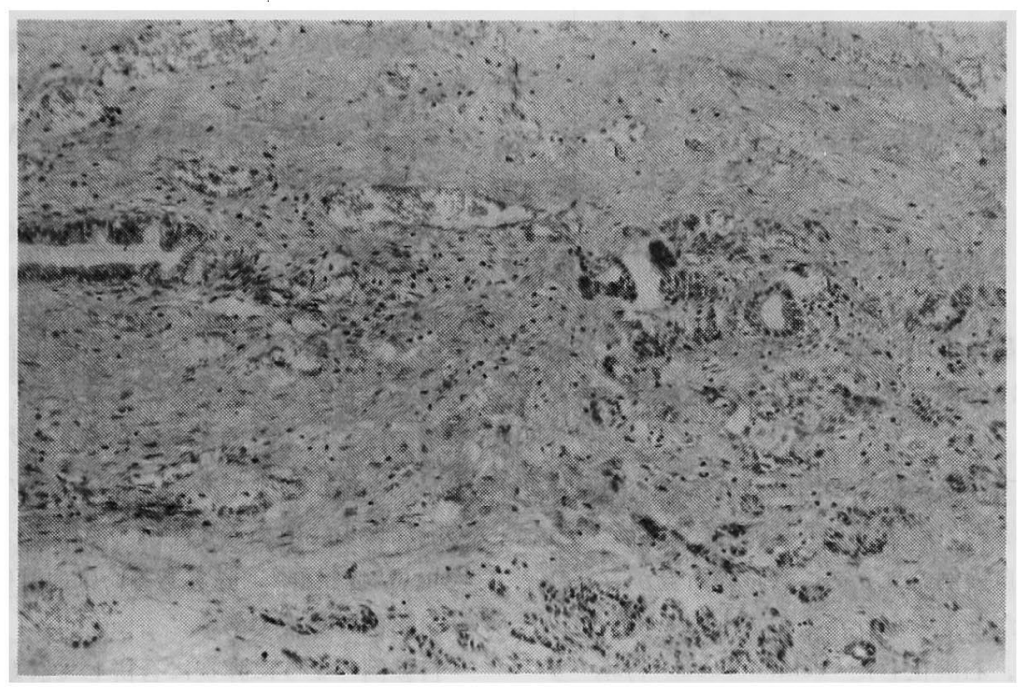

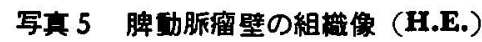

内膜はその粠造が乱れ fibrous に肥厚している。軽度の炎症性細胞の浸潤をみる。 内腔面には血栓の付着をみる。

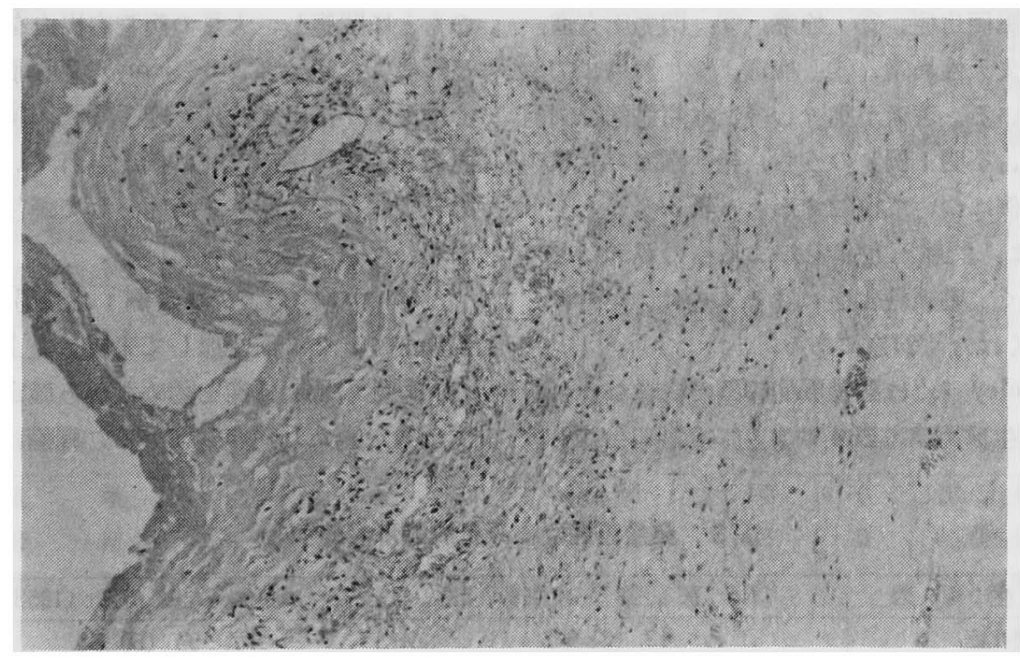

高度に肥厚し，脾門部の血管壁には一部でフィブリン血 栓の付着をみる.脾の洞は高度に払張し, 内皮細胞はや や目立って立方状を示すまた，その隔壁は線維性に肥 厚し、いわゆる fibroadenie の所見を呈する。

術後経過：順調で，8月17日略治退院した。術後約 1 年释過した現在む, 腹痛発作は全くなく, 臨床検査でも
表 2 のごとく勝炎や糖尿病の所見はなく社会復㷌してい 万。

\section{考按}

選択的血管撮影による脾動脈瘤の術前䛦断は，欧米て 1965年 Baum らが，また本邦で1967年佐藤ら"がそれ ぞれ初めて成功している. 本邦での脾動脈瘤の報告は, 
表 2 退院時の検查成较

\begin{tabular}{|c|c|c|c|c|c|}
\hline \multicolumn{2}{|c|}{ アミラーゼ } & \multicolumn{4}{|l|}{ OGTT } \\
\hline 尿 & 316 Somogyi $u$. & 血栯値 & インスリ & リン值 & 榶 \\
\hline 血清 & 140 & 0 分 & $97 \mathrm{mg} / \mathrm{dl}$ & $2.2 \mathrm{u} / \mathrm{ml}$ & $(-)$ \\
\hline \multirow[t]{5}{*}{ 一般険血， } & 肝機能等に異常なし & 30 & 126 & 9.1 & $(-)$ \\
\hline & & 60 & 133 & 10.1 & $(-)$ \\
\hline & & 90 & 134 & 10.6 & $(-)$ \\
\hline & & 120 & 80 & 4.4 & $(-)$ \\
\hline & & 180 & 74 & 2.0 & $(-)$ \\
\hline
\end{tabular}

1911年以来63例を数えるが，このうち血管撮影により術 前診断されたものは39例で，1968年以後の症例がはとん どである。

腹部単純レ線像での左季肋部の円形石灰化像. 透視時 の胃後壁の拍動性陰影欠損等です脾動脈瘤を診断し得る とされているが，自験例のよらにこれらの所見がみられ ない症例むあり，たとえみられたとしても肝・脾・腎・ 副腎の石戻化垔胞，石灰化した echinococcus cyst, リ ンパ腺石灰化あるいは他の石灰化腫瘤との政別を要す る゙ため，確定診断には腹腔動脈撮影が是非とも必要で ある。

発生原因 : Owens ら゙)によれば, 脾動脈瘤の発生原 因として, (1) 動脈硬化症, (2) 栓塞, (3) 門脈圧穴進 症，(4) 血管壁の先天性異常，(5) 梅毒，(6) 外傷，(7) 感染などをあげている．著者が集計し得た本邦症例63例 （男14例，女48例，不明 1 例）の5ち, 発生原因の記载 がみられたもの54例について検討すると，表 3 のことく であり，本邦では，門脈圧六進症によるものが56\%を 占めて非常に多く，動脈硬化症によるむのは，Owens ら の)報告はど多くはなく24\%である，

なた，最近 Stanley ら゙は脾動脈瘤60例の倹討から， 脾動脈瘤をその発生原因より表 4 のように5 型に分類し
ていて, IV型の高血圧症中動脈硬化症の女性または多産 婦に発生したものが58\%にも及んでいる．しかし，本邦 症例では，17\%に過ぎずむしろ II 型の門脈圧立進症に発 生したものが大半である. 本邦症例のらち， II 型の動脈 の限局性炎症による 4 症例の原疾患は，それぞれ梅毒"， Behçet 症候群 ${ }^{\text {() }}$ ，膵炎あるいは血管壁先天性異常9 およ び自験例の膆炎である。

自験例のように粹炎に合併して脾動脈瘤がみられた症 例は非常に少なく，本邦で 1 例，欧米で 4 例の報告が散 見出来るに過ぎない。

これらの各症例について，以下に紹介する。

- 烟尾 ら”）の報告例：38歳男子, 急性虫垂炎の診断 のもとに開腹し，大量の腹腔内出血を認める．後日血管 造影にて，起始部より $3 \mathrm{~cm}$ の脾動脈に， $4.5 \times 5 \mathrm{~cm}$ 大 の動脈瘤が描出される．超手拳大の陳旧性血腫中の脾動 脈瘤が，膵体尾部と共に摘出されている．門脈王六進や 動脈硬化などを認めす病因として既往の膵炎あるいは血 管壁の異常が考えられている。

- Hughes $5^{10)}$ の報告例：48歳男子，5年前から心窝 部痛あり，2 日前吐血して来院，左上腹部に径約 $10 \mathrm{~cm}$ の拍動性の硬い腫瘤を認めながら確定診断がつかず，再 度吐血をきたし開腹している．腫瘤は，脺体尾部と直换

表 3 発生原因別にみた脾動脈瘦症的数

\begin{tabular}{|c|c|c|}
\hline 発 生 原 因 & 本 邦 集 計 (1977 年) & Owens らの菓 計 (1953 年) \\
\hline 動脈硬化症 & $13(2496)$ & $96(6096)$ \\
\hline 栓塞 & 0 & $37(2396)$ \\
\hline 門服圧亢進症 & $30(5696)$ & $32(209)$ \\
\hline 血管壁の先天性異常 & $7(139)$ & $16(10 \%)$ \\
\hline 梅毒 & 1 & 9 \\
\hline 外賃 & 0 & 4 \\
\hline 感染 & 3 & 3 \\
\hline 不明 & 9 & 43 \\
\hline 計 & 63 & 204 \\
\hline
\end{tabular}


したかにみえる脾動脈瘤で，病着した胃体部後壁の一 部，席，脾と共に摘出されている．摘出標本では，動脈 瘤の径は約 $8 \mathrm{~cm}$ あり，球状で壁は厚く，層状の血拴や 血塊を容れ，脺組織は小葉の萎樎や炎症性細胞の浸潤が みられ，慢性膵炎像を示していて，脾動脈瘤との関連が 強調されている.なお本症例は術啳糖尿病となってい る.

・ Lower ら ${ }^{11)}$ の報告例：16歳男子，腹痛，下血が続 くめ胃十二指腸に異常所見なく，試験開腹にて，Treitz 数帯の左側空腸に瘜着した尰瘤を認める。この腫瘤は, 脾門よりの血管と連なり脺に密着しているため膵尾部と 共に摘出されている，摘出標本では，脺尾部組織中に層 状血栓を容れた動脈瘤があり，その外壁は線維・筋組織 であるが，内側は組織化したあるいは新蟹な血栓よりな る.䏽は線維化が著明で，外分泌腺は消失し小葉の萎縮 や尊管の桩張をみている。

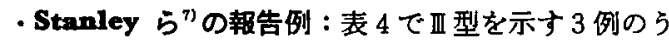
ち，2例が膆炎によるものである，1 例は，28歳男子， 急性䏽炎にて脾動脈瘤を形成し脺仮性栾胞に破裂して腹 腔内に多量の出血をみている。他の1例は，62歳男子， 慢性膵炎経過中，脾動脈瘤が膆仮性䔶胞に破裂し，胃内 へ大量出血している。

Stanley ら $ら^{7} は ，$ III型の動脈瘤の発生原因は，膵炎， 穿通性胃漬湯，敗血症性血栓あるいは外傷などで，動脈 周囲资または動脈内膜炎上り動脈瘤が形成されると考え るのが一般的であろうと述べている．なお，同㥞の原因 で胃十二指腸動脈に動脈瘤が発生した症例を Abrams $ら^{12)}$ が報告している. 彼は，特異的あるいは非特異的炎 症性疾患，例之ば胆毫资により肝動脈分枝に動脈瘤が発
表 4 Stanley の分類による脾洏脈虎应例数

\begin{tabular}{|c|c|c|}
\hline & $\begin{array}{c}\text { Stanley } \\
(1974)\end{array}$ & $\begin{array}{c}\text { 本邦集計 } \\
\text { (1977) }\end{array}$ \\
\hline I 型：動脈形成不全 & 8 & 7 \\
\hline II 型：脾嗹を伴う門脈圧え進症 & $6(10 \%)$ & $30(57 \%)$ \\
\hline III型：動脈の限局性炎症 & 3 & 4 \\
\hline $\begin{array}{c}\text { IV 型：女性；多産，高血圧症 } \\
\text { 動㟲硬化症 }\end{array}$ & $35(58 \%)$ & $9(17 \%)$ \\
\hline $\begin{array}{c}\mathrm{V} \text { 型：男性 ; 高血压症 } \\
\text { 野脈硬化症 }\end{array}$ & 8 & 3 \\
\hline 計 & 60 & 53 \\
\hline
\end{tabular}

生する ${ }^{13)}$ ように，脺炎に批いてもその炎症の波及が周辺 血管に動脈瘤を発生せしめるであるうと述べている．自 験例は，7年前より膵炎の加療を受けていたが，激痛発 作を繰返しており，腹控動豚撮影にて初めて腫動脈瘤の 存在が判明されたすので，脾動脈瘤，膆仮性要胞および 膵塤死組織の摘出により，脺炎発作が消失している。本 症の発生原因は，先天性血管壁異常によるものか，脺の 著明な炎症の波及によるものかは烟尾ら”の症例のごと く明らかではない，しかし，先天性血管壁異常による脾 動脈瘤が腈実質や脺管を压迫して膆资を引き起こしたと も推測できるが，上記の各症例報告括よび摘出標本の組 織像あるいは術後の膵炎症状の消失や臨床検查值の正常 化から考察すれば，本症例も動脈の限局性炎症が原因で あるとするのが妥当であろう。

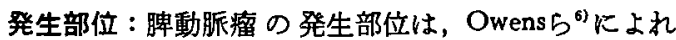
ぱ，主枝に $72 \%$ ，分枝に $26 \%$ ，両枝に6\%発生してお。 り，本邦の集計では（表 5 ），主枝に28\%，分枝に66\%

表 5 発生原因別脾动脈窗発生部位

\begin{tabular}{cc|c|c|c|c|c|c}
\hline & & 動脈硬化症 & 阴脈圧元進症 & 先天性壁異常 & 炎症 & 不明 & 計 \\
\hline 主 & 枝 & 6 & 2 & 2 & 3 & 0 & $13(28 \% 6)$ \\
分 & 枝 & 4 & 22 & 4 & 1 & 0 & $31(66 \% 6)$ \\
両 & 枝 & 0 & 1 & 1 & 0 & 1 & $3(6 \%)$ \\
\hline
\end{tabular}

表 6 発生原因別脾功脈㢈発生個数

\begin{tabular}{|c|c|c|c|c|c|c|c|}
\hline & & 動脤硬化症 & 門脈圧元進症 & 先天性壁異常 & 炎症 & 不明 & 計 \\
\hline 1 & 個 & 8 & 13 & 3 & 3 & 1 & $28(5696)$ \\
\hline 2 & 個 & $1\} *$ & $53 * *$ & 2 & 1 & 2 & $11(2296)$ \\
\hline & & $2^{J}$ & $6^{3}$ & 1 & 0 & 2 & $11(2295)$ \\
\hline & & 11 & 24 & 6 & 4 & 5 & 50 \\
\hline
\end{tabular}


また両枝に $6 \%$ 発生している. 本邦で分枝に多く発生し ているのは，原疾患が動脈硬化症よりも門脈圧六進症が 多いためと考えられる。

発生個数：脾動脈瘤の発生個数は, Owens $5^{6 /}$ の報告 では，1個のみ $70 \% ， 2$ 個 $11 \% ， 3$ 個以上 $13 \%$ となって おり，本邦集計では（表 6). 1 個のみ $56 \% ， 2$ 個および 3 個以上ではそれぞれ $22 \%$ と数数の発生が多くみられて いる。これるまた原疾患として動脈硬化症より門脈圧元 進症が多いことによるのであろう。

功脈瘦破裂頻度：脾動脈瘤の自然破裂の頻度は，

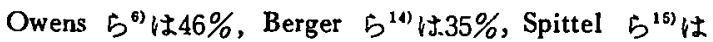
$21 \%$ と高頻度の報告を行なっているが, Stanley ら”は $5.3 \%$ に過ぎず，II型の资症珄動脈瘤を除くと破裂例は ないと述べている. 本邦の集計では, 21\% (13/63)が 破裂をきたしており，それらの原疾患別内分けは，動脈 硬化症, 先天性壁異常, 動脈の限局性炎症が各 3例, 不 明 4 例であった。 な拈 Owens ら゙にによれば，破裂症例 中䄪 $46 \%$ d double rupture ${ }^{16)}$ で残りは single rupture で あると報告している。

他滕器への破裂：Owens $5^{6)}$ は破裂症例中，胃内人 10 $\%$ ，結腸へ $7 \%$ ，膵へ $4 \%$, 脾静脈へ1\%破裂していた と報告している。 また, Jones $5^{17)}$ む胃内へ $11.1 \%$, 脺 へ $6.3 \%$ ，結腸へ $7.8 \%$ の破裂をみている.さらに特殊な 場合として，大量の上部消化管出血を来たしながら，出 血部位が判明せず, 血管撮影で初めて脾動脈瘤が描出さ れ，手術により脾動脈瘤の脺管への破裂が確認された症 例が: Sandblom ${ }^{18)}$ により 2 例, 添野ら ${ }^{19)}$ により最近 1 例 報告されている。

\section{総 括}

31歳男子で，数年にわたる膵炎加療中に，選択的腹腔 動脈撮影の施行により脾動脈瘤が発見され，手術にて脺 体尾部の著明な変性萎樎と共に腈娈胞中の動脈瘤を確認 して, 䏽体尾部, 脾と共にこの動脈瘤を摘出し, 脺炎を 治落せしめた 1 例を報告した。

著者が集計したところでは，本邦での脾動脈瘤の報告 は自験例を入れて63例あり，脾動脈瘤の発生原因は門脈 圧六進症が大半で, 動脈硬化症は欧米はど多くなく，そ の他血管壁の先天性異常および動脈の限局性炎症であっ た.

動脈の限局性炎症のうち膆炎が原因となり，脾動脈瘤 が形成された症例は自験例を入れてわずか6 例の報告が あるのみで，今後血管撮影により膵炎症例にも脾動脈瘤 が多数発見されるものと思われる。
稿を終るにのぞみ，こ校閲を賜わつた和歌山医大消化 器外科学教室勝見正治教授および第一病理学教室小田富 雄教授に深䜊します。

\section{萦考文献}

1) Stanley, J.C., Thompson, N.W. and Fry, W. J.: Splanchnic Artery Aneurysms, Arch. Surg. 101:689-697, 1970.

2) 吉田準一郎：稀有なる鸾状脾動脈瘤の 1 例. 医 事新報, $828: 569-580,1911$.

3) Baum, S., Greenstein, R.H., Nusbaum, M. et al.: Diagnosis of Ruptured, Noncalcified Splenic Artery Aneurysm by Selective Celiac Arteriography, Arch. Surg. 91: 1026-1028, 1965.

4）佐藤寿雄, 能登 阵，須田䔨夫他 : 脾動脈瘤に つい, 外科, 29 : 998-1004, 1967.

5) Carlisle, B.B. and Lawler, M.R.: Aneurysm of the Splenic Artery, Report of Ten Cases, Amer. J. Surg. 114: 443—447, 1967.

6) Owens, J.C. and Coffey, R.J.: Aneurysm of the Splenic Artery, Including a Report of 6 Additional Cases, Surg. Gynecol. Obstet. int. abst. surg. 97: 313-335, 1953.

7) Stanley, J.C. and Fry, W.J.: Pathogenesis and Clinical Significance of Splenic Artery Aneurysms, Surgery 76: 898-909, 1974.

8) 小西理雄, 安住修三, 信岡 亘他: Lienomesenteric Trunk に伴う脾動脈瘤の 1 手術経験, 外 科, $39: 635-637,1977$.

9) 畑尾正彦, 岡村 孝, 里見 昭他：脾動脈瘤の 1 治験例，日外会誌，77:1727，1976.

10) Hughes, E.S.R. and Joske, R.A.: Aneurysm of the Splenic Artery and Chronic Pancreatitis, with a Report of Successful Surgical Resection, Med. J. Australia 2: 188-190, 1955.

11) Lower, W.E. and Farrell, J.I.: Aneurysm of the Splenic Artery, Report of a Case and Review of the Literature, Arch. Surg. 23: 182$190,1931$.

12) Abrams, R.M., Kulkarni, A.V., Beranbaum, E.R. et al.: Aneurysm of the Gastro-duodenal Artery, Br. J. Radiol. 42: 384-385, 
1969.

13) Guida, P.M. and Moore, S.W.: Aneurysm of the Hepatic Artery. Report of Five Cases with a Brief Review of the Previously Reported Cases, Surgery 60: 299—310, 1966.

14) Berger, J.S., Forsee, J.H. and Furst, J.N.: Splenic Arterial Aneurysm, Ann. Surg. 137: 108-110, 1953.

15) Spittel, J.A., Fairbairn, J.F., Kincaid, O.W. et al.: Aneurysm of the Splenic Artery, J.A. M.A. 175: 452-456, 1961.

16) Sherlock, S.P.V. and Learmonth, J.R.: Aneu- rysm of the Splenic Artery: With an Account of an Example Complicating Gaucher's Disease, Br. J. Surg. 30: 151-160, 1942.

17) Jones, E.L. and Finney, G.G.: Splenic Artery Aneurysms, A Reappraisal, Arch. Surg. 97: $640-647,1968$

18) Sandblom, P.: Gastrointestinal Hemorrhage through the Pancreatic Duct. Ann. Surg. 171: $61-66,1970$.

19）添野武彦，柿崎五郎，藤原慶之他：膵内への脾 動脈瘤破裂による上部消化管内大量出血の 1 治 験例. 外科治療, $31: 227-233,1974$. 